\title{
Short Comparison of Trade Policies in Thailand, Myanmar and Laos
}

\author{
Bryanna Till' ${ }^{1}$ and Kishore G. Kulkarni2* \\ 'Korbel School of International Studies, University of Denver, 2201 South \\ Gaylord Street, Denver, CO 80208, USA \\ 2Distinguished Professor of Economics, Chief Editor, International Review of Business and Economics, \\ Campus Box 77, P. O. Box 173362, College of Business, Metropolitan State \\ University of Denver, Denver, CO 80217-3362, USA
}

\begin{abstract}
Many individuals remember the Golden Triangle as the drug trafficking center of the World. However, Thailand, Myanmar and Laos have each taken contrasting paths of economic development. The paper aims to explore the countries' varying approaches to tariff policy and its effects on the economy. The first part of the paper describes some of the important theoretical perspectives to international trade such as comparative advantage, the Heckscher-Olin theorem and the gravity model, before discussing tariffs and other obstructions to free trade. The next part of the paper delves deeper into the tariff policies of the Golden Triangle countries and their effects. Thailand emerges as the most economically successful of the three countries and she has successfully used tariffs to implement more sustainable development. Myanmar still has several tariffs and sanctions, except for when dealing with other ASEAN countries. The instability of the government is a concern for Myanmar if they want to become more successful. The Laotian government has recently cut most tariffs and is starting to see much more development and economic growth as a result. The paper concludes that, free trade is imperative to economic success and free trade is perfectly represented in the differing stages of development that the three counties currently occupy. Hopefully, each can continue to develop and prosper through more liberalization of their economies.
\end{abstract}

Keywords: International Trade Benefits, Laos, Myanmar, Thailand, Trade Policies

\section{Introduction}

The Golden Triangle was once known as the infamous drug trafficking center of the world. Thailand, Myanmar formerly known as Burma and Laos were all involved in the opium trade during the opium epidemic in the 1960's-1970's. As of today, these countries have succeeded and failed economically in their own ways. Before the Asian financial crisis in the 1990's, Thailand had a booming economy, providing many jobs for their citizens and bringing millions out of poverty (World Bank, 2021). Today, Thailand is still a booming economy due to tourism. Myanmar is a different scenario. They are still dealing with a lot of human right violations and Myanmar is one of the least developed countries, its economy is primarily focused on agriculture (Encyclopedia Britannica, 2021). Laos is similar to Myanmar in terms of development. It is one of the least developed and one of the poorest countries in Asia, but there is still some economic growth occurring in the country (Walter, 2016).

This paper aims to compare the different tariff policies that each country has. The theoretical portion will discuss components of International Trade Theory (comparative advantage and the Heckscher-Olin theorem). The next section will cover objections to free trade like tariffs and non-tariff trade barriers. The paper will then examine various trade policies before applying them to Thailand, Myanmar and Laos. The third part will provide research

${ }^{*}$ Author for correspondence 
on the current trade policies of the Golden Triangle countries. The last part will provide a better understanding of the different tariff policies implemented by Thailand, Myanmar, and Laos.

\section{Part One}

\subsection{Theory of International Trade}

International Trade Theory is essential for a country to develop. Even today Standard Trade Theory is vital for modern economics (Salvatore, 2020). The first substructure of the International Trade Theory is comparative advantage, which critiques absolute advantage and has become an important argument for free trade. Comparative advantage is about the efficiency in the production a good or service. For instance, in a twocountry scenario, Country A and Country B produce the same product, if Country A is more efficient in making that product, then both countries should still produce those two goods. After determining the opportunity cost, the countries would then aim to specialize in one good over the other. David Ricardo argued that both countries should still trade with one another.

Eli Filip Heckscher and Bertil Ohlin from Sweden expanded Ricardo's ideas leading to the Hechsher-Ohlin Theorem (2021). They both stated how trade could be conducted between two countries that have the same capabilities based on the factor of endowments. The Hechsher-Ohlin Theorem looks at counties' that are factor abundant. This theorem then looks at which countries are labor abundant and produce labor intensive goods, while countries that are capital abundant should focus on capital intensive goods. In later years Paul Samuelson and Wolfgang Stolper expanded on the Hechsher-Ohlin Theorem and provided information on post trade between countries (Schmitz, 2012). They observed that after trade the labor abundant country will likely see an increase in wages and the capital abundant country will possibly see a surge in rent.

The gravity model of international trade is another important reason why countries trade with another. With countries that have a larger economy and are close to each other geographically, they are more likely to trade. That is because of smaller logistical costs through being in closer proximity and having similar demands. It is an important explanation for several trade agreements throughout the world.

\section{Part Two}

\subsection{Arguments against Free Trade}

Neoclassical economists determined that Standard Trade Model is an essential aspect to developing economically. There are, however, other people that argue against free trade. These individuals would argue for protectionist policies such as tariffs, despite empirical evidence consistently supporting liberalism over protectionism. These are the most common ways that a country can obstruct free trade. But there are also other things that can hinder free trade, like non-tariff trade barriers. These include quota policy, Voluntary Export Restraints (VER), Domestic Content Requirement (DCR), Intellectual Property Rights (IPRs) and various ways of dumping.

Tariffs and quotas have essentially the same effect on a country's economy when they are implemented. That is because they can raise the domestic producer's surplus and decrease the consumer's surplus. Intellectual Property Rights are put into effect to protect brand' images and ideas so that other people cannot make a profit from them. IPRs are critical for International Trade and trust between trading countries. Countries that do not comply with IPRs can be subject to sanctions which are meant to help countries follow the IPRs rules.

Newly developed countries as well as less developed countries often use protectionist policies in the hopes of protecting domestic markets and being more competitive. The most used protectionist arguments are the National Defense argument as well as the Infant Industry argument. The National Defense argument states that it is necessary to protect certain goods with tariffs to ensure continued domestic production in case of heightened tensions or threat of war (Schmitz, 2012). Infant Industry has been commonly argued from developing countries. However, the Infant Industry is often criticized because of the monopolization of domestic markets and it destroys the incentive to compete with other markets and produce goods with quality and efficiency. The National Defense argument has been around since the beginning of time because countries have always sought to outperform their competitors.

\section{Part Three}

\subsection{Tariff Policies in Thailand}

Even though Thailand is pro-free trade, occasionally they use tariffs. In the early years of Thailand's modernization, 
the government executed a two-tier tariff policy around 1932-1963. The two-tier tariff policy is also known as Tariff Rate Quota (TRQ) (Praditsarn, 2005). TRQ combines the import quota and the tariff to regulate imports. With the two-tier tariff policies, Thailand had to please domestic groups that demanded tariff protection as well as international trade partners wanting to export (Praditsarn, 2005). Currently Thailand is the U.S $20^{\text {th }}$ largest goods trading partner. The total of exports and imports total in 46.7 billion dollars (United States government). In later years, Thailand has followed a more liberal economic policy.

The Thai people are notorious for shopping, ranking fifth in the world for being the biggest shoppers (editors of Asia News Monitor, 2013). Many Thai citizens travel out of their country and purchase many luxury items. Recently there has been a proposal to waive import tariffs on these luxury products like watches, clothing and cosmetics. With that in place, many Thais would be more likely to purchase it at home instead of flying abroad (editors of Asia News Monitor, 2013). By cutting the 30\% import tariff on those goods, Thailand can compete with surrounding countries and territories like Hong Kong and Singapore (editors of Asia News Monitor, 2013). With Thailand proposing to cut this tariff, Thailand can start competing with their surrounding countries and territories.

Another tariff is the Feed-in-Tariff (FiT). The electricity market in Thailand has a monopoly on the electricity distribution market (Tharisung, 2020). Most of the energy in Thailand comes from fossil fuels, which contributes to pollution. In 2007, the Thai government created incentives for producing renewable energy sources. Through the Thai government implementing the FiT tariff, they want to promote the use of renewable energy (Tharisung, 2020). Even though the government subsidizes the use of renewable energy, the primary source of energy is still natural gas. By implementing this tariff, it creates economic loss because it does not provide a correct price for power generators (Tharisung, 2020). With the FiT, Thailand is taking initiative to combat climate change.

Thailand does not enforce a lot of tariff policies and has been an important advocate of liberalism in the region (Herman, 2021). By pursing liberal policies, Thailand has made important progress in its economic development by restricting the use of tariffs and other restrictions to free trade.
The chart below illustrates the highest tariff products that are imported into Thailand. The chart displays that undenatured ethyl alcohol has the highest percentage of tariffs at $300 \%$.

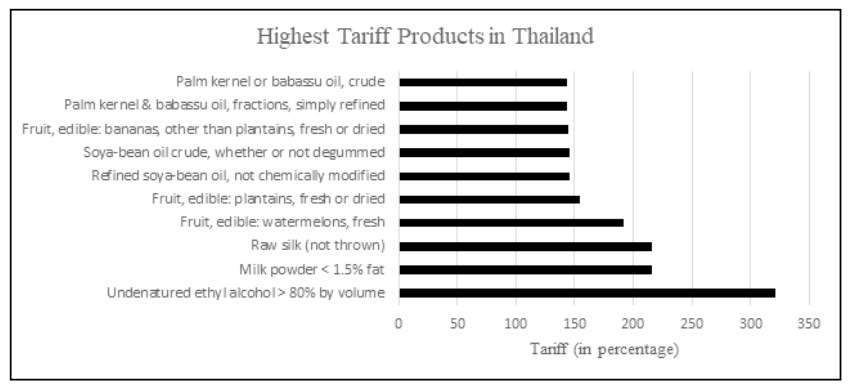

(OEC Thailand).

\section{Tariff Policies in Myanmar}

The last couple decades, Myanmar has struggled with human rights issues as well as an unstable government. In the 1960's Myanmar was not opposed to trade. The military of Myanmar started to become wealthy because they were exporting teak, rubies and rice. Despite the anti-West government propaganda, Myanmar exports did not diminish (Anguelov and Bryant, 2015). Myanmar trade with Communist countries increased but decreased by the end of the 1960's. In the 1970's, exports increased with India and with the Soviet Union. By the end of the 1980's the State Law and Order Restoration Council (SLORC) was established to control the country and change the name to Myanmar (Anguelov and Bryant, 2015). Because Myanmar established a military coup that killed and arrested protestors, the United States refused to acknowledge SLORC and imposed sanctions. The American sanctions came in the form of an arms embargo and the refusing of economic assistance for humanitarian needs (Anguelov and Bryant, 2015). Myanmar continued to abuse human rights and the United States imposed more sanctions in the 1990's. Due to Myanmar's continued abuses, President Bill Clinton banned new investments in Myanmar by US companies and individuals under the Executive Order 13047 (Anguelov and Bryant, 2015). Myanmar remained unresponsive to the international pressure. As of 2019, Myanmar has approximately 22.4 billion of dollars in exports and 28.6 billion of dollars in imports (OEC Myanmar). Today they are still breaking human right laws and are involved in human trafficking as well. 
While Myanmar is still being sanctioned by the United States, many countries still trade with Myanmar. China and Russia are two of the most important trade partners for the country (Anguelov and Bryant, 2015). Myanmar is still a member of the Association of Southeast Asian Nations (ASEAN) which has allowed them to have business ties with Thailand, India, Singapore, and Japan, among others. The location of Myanmar and the value of trade they have to offer have been beneficial to other Asian countries in ASEAN (Anguelov and Bryant, 2015). Myanmar's important trade relationships in the region are supported by the gravity model.

Like Thailand, Myanmar is pushing toward sustainable energy sources and has therefore imposed longsubsidized power tariffs. By increasing a sustainability tariff and promoting renewable energy, Myanmar hopes it can attract other nations and create more jobs, which will generate economic growth (Asia News Monitor, 2019). Myanmar's economic development is unbalanced regionally. Urban areas have much more luxury and energy than the rural areas of the country. This increase in price on energy will offset the losses on tariff subsides but might continue to be an issue (Asia News Monitor, 2019). While the tariff increase is higher for residents, it is not as high for nonresidents like embassies and businesses. That could be a shock to the Myanmar citizens because many of them have taken the cheap government subsided energy for granted (Asia News Monitor, 2019). The increase in tariffs may not benefit the country economically. Through increasing tariffs, inflation may increase which could hinder the peoples' purchasing power (Asia News Monitor, 2019). The Myanmar government's plans are similar to the infant industry argument but would likely harm the economy in the long run.

In total, tariffs have been utilized by the Myanmar government and aims to improve the economy. However, Myanmar has not been successful because they continue to obstruct free trade, their political atmosphere remains unstable and because of the continued enforcement of sanctions by the international community. The US has been unsuccessful, however, in convincing some key countries to follow suit, such as China, Russia, Thailand, India, Japan and Singapore who continue to trade with Myanmar. Myanmar is helped by its membership in ASEAN. Lastly, Myanmar increased the long-subsidized tariff promoting renewable resources similar to Thailand. Myanmar pursues more protectionist policies than Thailand.
The chart below illustrates the various products that have the highest tariffs imports into Myanmar. As shown below, many of the products that have the highest tariff rates are alcoholic beverages.

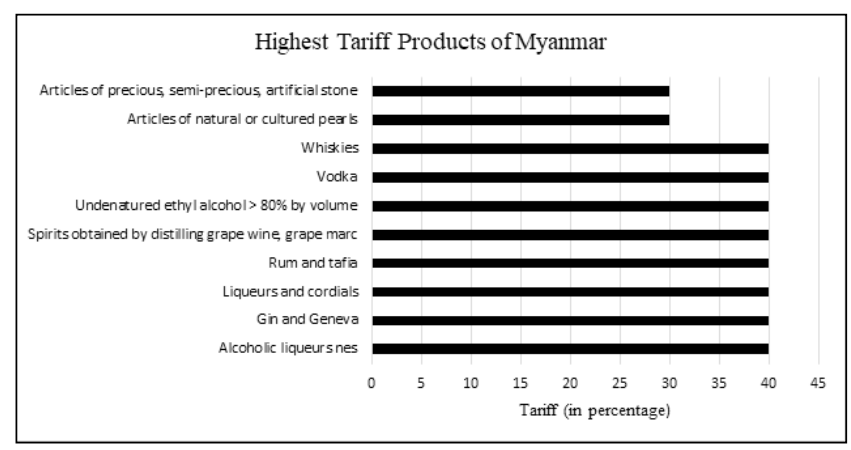

(OEC Myanmar).

\section{Tariff Policies in Laos}

Laos is considered to be one of the least developed countries in Asia. While they remain poorer than other countries in the region, they have been receiving critical assistance from China. With the assistance from China, parts of Laos have been able to develop more than others. More recently Laos has been cutting its tariffs on several countries and some countries are even cutting tariffs with them. Currently Laos is the $154^{\text {th }}$ largest trading partner of the United States with approximately 165 million dollars in imports and exports between the two countries (United).

China has recently agreed to cut $97 \%$ of tariffs on Laotian goods leaving almost all of Laotian exports into China to be duty free (Washington, 2020). China recently implemented the Least Developed Countries initiative providing assistance to countries like Myanmar, Cambodia and Laos through reduced tariffs. Many Laotian people are worried that the initiative will only benefit China and not benefit their respective countries. But ASEAN stated that it will be a crucial victory for Laos and that several other small countries that are a part of ASEAN should take advantage of the help from China (Washington, 2020). Most of the products that are exported to China from Laos are agricultural items. The crops that are grown are grown on Chinese leased land then exported to China (Washington, 2020). With the reduction of tariffs, China has become strict on the quality of what is imported into China. Laos products are not easily accepted with the $0 \%$ tariff policy, creating an unofficial trade barrier for Laos (Washington, 2020). Despite China's reduction of Laotian 
goods, Laos has struggled to meet the required quality and has hurt the trade in some cases.

In 2019, Laos decided to reduce import tariffs on approximately 8,500 products from ASEAN countries. Laos reduced the import tariff to $0 \%$ with the intent of participating in ASEAN Free Trade (Bangkok, 2019). The 8,500 products that Laos reduced import tariffs on represent $89 \%$ of the total products Laos trades with other countries that are members of ASEAN Trade in Good Agreements or (ATIGA). Laos can still impose 10\% of import tariffs because it is vital for their economic stability, which only includes 325 products (Bangkok, 2019). Laos is hurting in domestic production and consumption and has been trying to improve it for multiple years. 50\% of goods sold in Laos are imports (Bangkok, 2019). In the effort to make ASEAN countries implement more liberal policies, Laos decided to reduce tariffs on imports from ASEAN countries.

As a member of the ATIGA, Vietnam and Laos have cut tariffs on each other's imports. Laos decided to cut approximately $50 \%$ of import tariffs from Laos into Vietnam, according to the Ministry of Finance in Circular 216 (Ministry of Finance, 2016). The circular also states that if the import tariffs in the ATIGA are higher than the tariff regulation in Most Favored Nation (MFN), the imported goods will be subjected to a $50 \%$ tax reduction. There will also be $50 \%$ tax incentives for some goods (Ministry of Finance, 2016). In 2015, tariffs were eliminated from $95 \%$ of goods from Vietnam to Laos. The agreement replaced the 1998 traded agreement between the two countries (Thai News Service Group, 2015). By signing this agreement Vietnam and Laos wanted to build a positive relationship (Thai News Service Group, 2015).

All in all, Laos has cut tariffs with several countries. To help Laos become a more developed country, China decided to cut import tariffs from Laos. While that can help Laos, many citizens think that it is hindering their development. In an effort to establish more ASEAN Free Trade Area Agreements, Laos has reduced tariffs on many goods from ASEAN countries. In efforts to build a stronger relationship with Vietnam, Laos and Vietnam reduced multiple tariffs from each other's imports.

The chart below displays the highest tariffs products that were imported into Lao from various countries. As shown below all of the imports have an equal percentage of the tariffs.

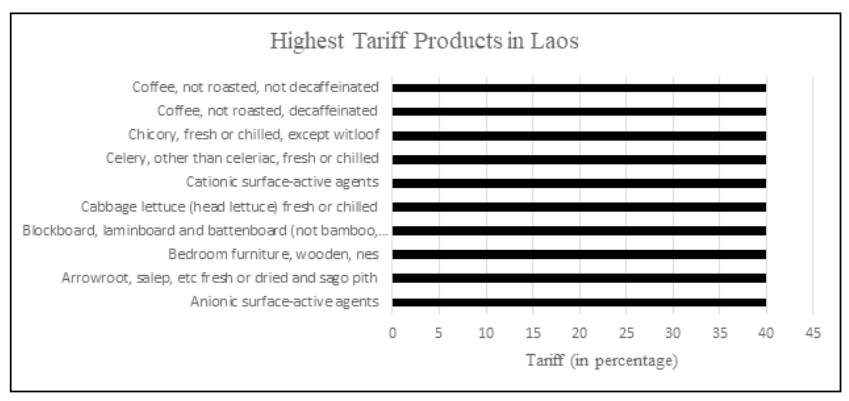

(OEC Laos).

\section{Summary and Conclusion}

In conclusion, two out of the three countries have more liberalized economies through moving towards free trade and reducing tariffs. In the 1930's Thailand has a twotier tariff that was in place which combined quota and tariff policies. After that policy ended, Thailand started to move toward a more liberalized market by promoting free trade. Thailand and Laos have made efforts in reducing tariffs with ASEAN countries and creating a freer trade environment. Thailand and Myanmar have similar tariffs to promote cleaner energy sources and to reduce fossil fuels. Myanmar has had sanctions put into place since the 1960's. The government has broken human right laws and has had multiple military regimes that the United States and most of the international community are against. However, most ASEAN countries did not support the US's sentiments and decided to not impose sanctions and also kept Myanmar in ASEAN. Because Laos is one of the poorest countries in Asia, China assisted Laos to diminish the import tariffs between them. Although the tariff reduction has not helped Laos as much as intended but rather hindered the Laotian economy in some cases. Laos and Vietnam reduced tariffs with one another to help build a stronger relationship between the two countries. Thailand is proof that free trade is a good accomplishment and Laos has started to see similar successes. Hopefully, Myanmar can follow suit of its Golden Triangle neighbors, and begin to liberalize their economy.

\section{References}

1. Anguelov, N., \& Bryant, K. (2015). Myanmar-20 years of sanctions and their lasting effect. Economic Sanctions vs. Soft Power. Palgrave Macmillan, New York. https://doi-org. du.idm.oclc.org/10.1057/9781137523761_3 
2. Asia News Monitor (2019, Jul 08). Myanmar (Burma): Myanmar's tariff hikes: Daring but worth the risk. Asia News Monitor Retrieved from https://du.idm.oclc.org/ login?url=https://www-proquest-com.du.idm.oclc.org/ newspapers/myanmar-burma-myanmars-tariff-hikes-daring-worth/docview/2252768762/se-2? accountid=14608

3. Bangkok (2019, Jan 28). Laos: Laos cuts import tariffs on over 8,000 products from ASEAN. Asia News Monitor Retrieved from https://du.idm.oclc.org/ login?url=https://www-proquest-com.du.idm.oclc.org/n ewspapers/laos-cuts-import-tariffs-on-over-8-000-products/docview/2171388041/se-2? accountid $=14608$

4. Encyclopedia Britannica, inc. (2021). Heckscher-Ohlin theory. Encyclopedia Britannica. https://www.britannica. com/topic/Heckscher-Ohlin-theory

5. Encyclopedia Britannica, inc. (2021). Myanmar: Additional Information. Encyclopedia Britannica. https://www.britannica.com/place/Myanmar/additional-info\#history.

6. Herman, N. (2021). Thailand's Trade Policies: Short Review of Successes and Shortcoming. International Review of Business and Economics Journal, 5(1):23-34. https://doi. org/https://www.irbejournal.com

7. Ministry of Finance (2016, Feb 04). Vietnam/Laos: Vietnam to cut tariffs on Laos imports. Asia News Monitor Retrieved from https://du.idm.oclc.org/login?url=https://wwwproquest-com.du.idm.oclc.org/newspapers/vietnam -laos-cut-tariffs-on-imports/docview/1762157224/se2 ? accountid $=14608$

8. OEC. (2019). Laos (LAO) Exports, Imports and Trade Partners. OEC. https://oec.world/en/profile/country/ lao\#tariffs

9. OEC. (2019). Myanmar (MMR) Exports, Imports, and Trade Partners. OEC. https://oec.world/en/profile/country/ mmr\#tariffs

10. OEC. (2019). Thailand (THA) Exports, Imports, and Trade Partners. OEC. https://oec.world/en/profile/country/tha
11. Praditsarn, N. (2005). Explaining high tariffs in the developing world: The case of two -tier tariffs in Thailand (Order No. 3171750). Available from ProQuest Central; ProQuest Dissertations \& Theses Global. (305444773). Retrieved from https://du.idm.oclc.org/login?url=https://wwwproquest-com.du.idm.oclc.org/dissertations-theses/ explaining-high-tariffs-developing-world-case-two/ docview/305444773/se-2? accountid=14608

12. Salvatore, D. (2020). International economics. Hoboken, NJ: Wiley.

13. Schmitz, A. (2012). International Trade: Theory and Policy. Public Goods and National Security and the StolperSamuelson Theorem.

14. Thai News Service Group (2015, Mar 04). Vietnam/Laos: Zero tariffs on 95 percent of goods from Vietnam, Laos. Asia News Monitor Retrieved from https://du.idm.oclc. org/login?url=https://www-proquest-com.du.idm.oclc. org/newspapers/vietnam-laos-zero-tariffs-on-95-percentgoods/docview $/ 1660150806 /$ se- 2 ? accountid $=14608$

15. Tharisung, K. (2020). Economic cost of the feed - in tariff (FiT) in Thailand. International Journal of Energy Economics and Policy, 10(4):356-363. https://du.idm. oclc.org/login?url=https://www-proquest-com.du.idm. oclc.org/scholarly-journals/economic-cost-feed-tarifffit-thailand/docview/2459622143/se-2? accountid=14608 https://doi.org/10.32479/ijeep.9367

16. Walter, M. (2016, March 25). Economic Growth and Trade: Laos. U.S. Agency for International Development. https:// www.usaid.gov/laos/economic-growth-and-trade

17. Washington, (2020). China removes tariffs on laos, but critics say barriers remain for lao companies. Washington: Federal Information \& News Dispatch, LLC. Retrieved from ProQuest Central Retrieved from https://du.idm. oclc.org/login?url=https://www-proquest-com.du.idm. oclc.org/reports/china-removes-tariffs-on-laos-critics-say/ docview $/ 2462121195 /$ se- 2 ? accountid $=14608$ 